\title{
(Re)Framing a Problem: Militancy in Question
}

\author{
André Luis Leite de Figueirêdo Sales*, 1 \\ Orcid.org/0000-0001-8607-7532 \\ Flávio Fernandes Fontes ${ }^{2}$ \\ Orcid.org/0000-0003-2036-8147 \\ Silvio Yasui ${ }^{1}$ \\ Orcid.org/0000-0001-5015-6634 \\ ${ }^{1}$ Universidade Estadual Paulista Júlio de Mesquita Filho, Assis, SP, Brasil \\ ${ }^{2}$ Universidade Federal do Rio Grande do Norte, Santa Cruz, RN, Brasil
}

\begin{abstract}
Even though "militancy" is frequently used in scientific literature and in the daily life of parties and social movements, there are few definitions of the term. Our goal is to convert the idea of militancy into a research problem. A Brazilian scientific literature review shows that the term is used either as an adjective, either as a noun. We conceptualize militancy as a methodology to produce collective action aiming to intervene, or to interfere, in current social norms. This methodology focuses on organizations such as parties and unions, characterized by strict discipline that aims to produce docility, commitment, and obeisance. Then, we show how New Social Movements (NSM) have created unconventional tactics and organizations, offering an alternative to the militant methodology. Organizing teams using horizontal arrangements, operating with decentralized and autonomous networks, recognizing the diversity of its participants, NSM are occupying the streets and reinventing the repertoires of collective action and protest. We suggest the use of the word "activism" to describe this methodology. By distinguishing militancy from activism we wish to re(frame) some problems in the Brazilian scene of political engagement and protest.
\end{abstract}

Keywords: Activism, militancy, subjectivity, social movements.

\section{Para (Re)Colocar um Problema: A Militância em Questão}

\section{Resumo}

Mesmo usado com frequência em literatura científica e no cotidiano de partidos e movimentos sociais, são escassas as definições do termo militância. Nosso objetivo é reconduzir a ideia de militância à condição de problema. Através de uma revisão de literatura nacional, mostramos que o vocábulo é

\footnotetext{
Mailing address: Av. Dom Antonio, 2100, Parque Universitário, Assis, São Paulo, CEP 19806-900. Fone: (18) 3302-5800. E-mail: andreluislfs@gmail.com, flaviofontes61@gmail.com e silvioyasui@gmail.com.

Este trabalho foi financiado em 2016 do através do processo 2015/26241-0 pela Fundação de Amparo à Pesquisa do Estado de São Paulo (FAPESP). Agradecemos o apoio da instituição
} 
empregado ora como adjetivo, ora como substantivo. Propomos definir militância como metodologia para produzir ações coletivas a fim de intervir, ou interferir, nas normas sociais vigentes. Essa metodologia privilegia como estruturas organizativas os partidos, os diretórios, as centrais sindicais e afins. $\mathrm{O}$ modo de funcionamento destas é marcado pela disciplina e visa produzir docilidade, comprometimento e obediência. Apresentamos em seguida como os Novos Movimentos Sociais (NMS) produziram alternativas táticas e organizativas à militância. Prezando por relações horizontalizadas; operando em redes descentralizadas e autônomas; reconhecendo a pluralidade dos interesses de seus atores, os NMS têm ocupado ruas e reinventado os repertórios de ação e de protesto. O termo "ativismo" é sugerido para designar essa outra metodologia. Ao diferenciar ativismo e militância objetivamos recolocar os problemas ligados ao campo da participação social, da contestação e dos protestos.

Palavras-chave: Ativismo, militância, subjetividade, movimentos sociais.

\section{Para (Re)Colocar un Problema: La Militancia en Cuestión}

\section{Resumen}

"Militancia" se utiliza con frecuencia en la literatura científica y en la vida diaria de los partidos y movimientos sociales, pero definiciones del término son escasas. Nuestro objetivo es llevar la idea de militancia a la condición de problema. Una revisión de la literatura brasileña muestra que el término se usa ocasionalmente como un adjetivo o como un sustantivo. Proponemos definir militancia como una metodología para producir acciones colectivas a fin de intervenir, o interferir, en las normas sociales vigentes. Esta metodología se centra en organizaciones como partidos y sindicatos. El funcionamiento de éstas está marcado por la disciplina y tiene como objetivo producir la docilidad, el compromiso y la obediencia. Entonces presentamos cómo los Nuevos Movimientos Sociales (NMS) han producido diferentes tácticas y organizaciones, constituyendo una alternativa a la militancia. Valorizando relaciones más horizontales; operando redes descentralizadas y autónomas; reconociendo la diversidad de los intereses de los participantes, los NMS han ocupado las calles y reinventado los repertorios de acción y manifestación. Se sugiere el término "activismo" para describir esta otra metodología. Al diferenciar activismo y militancia deseamos recolocar los problemas relacionados al campo de la participación social y manifestaciones.

Palabras clave: Activismo, militância, subjetividade, movimientos sociales.

On March 4, 2016, after evaluating the coercive conduct of the former president of the republic Luiz Inácio Lula da Silva, in order to give testimony to the Federal police as a "kidnapping" and an affront to democracy, the incumbent President of the Workers' Party (PT), Ruy Falcão, in a YouTube video, calls on the militants and the militancy of the PT to mount a vigil on the state directorates, while awaiting the guidance from the national leadership. Ruy Falcão points out that the militants and the militancy of the "Central Única dos Trabalhadores" (CUT) would follow the same orientation. The reaction to the speech was intense, and made the idea that this convocation could generate turmoil, conflicts and disorder in urban centers circulate in the national press. This fact, which occurred at a time we were studying the methodologies to produce collective action aiming to intervene, or to interfere, in current social norms, has made the need to try to answer one question even more poignant: What are we saying when we use the word militancy?

Silva (2004) warns about the risks arising from the naturalization of some ideas, such as social in Social Psychology:

It is first of all necessary to stop taking social as evidence and to constitute it as a problem, 
that is, ... to constitute it as a multiplicity necessarily built from a relation of forces in a given historical field. (Silva, 2004, p. 13)

Transposing the author's considerations to the field of militancy, it is our goal in this article to redirect the idea of militancy to the status of a problem. To miss truisms, to produce doubt and to be dissatisfied with certainties is the argumentative tactic employed here. After all, "there are moments in life when the question of whether it is possible to think differently from what one thinks and perceive differently from what one sees is essential to continue to see or reflect" (Foucault, 1977, p. 19).

In order to bring the idea of militancy back to the condition of problem, we made the following path: (a) literature review investigating the uses of the notion of militancy, which leads us to propose a definition and a characterization of it in the sections "Searching for Words" and "Militancy: some whats, whichs and a few buts"; (b) a problematization of the naturalized use of the notion of militancy in the light of its comparison with what would be an example of another methodology used to produce collective action to intervene, in current social norms, namely activism. This second part is carried out in the sections "The Attentive Look at Repetition Makes the Difference" and "Activate and Occupy". In the end, we hope to have launched theoretical tools that initiate a debate to better understand phenomena of collective action such as the repertoires, the contestation tactics and the protests performances. Replacing the problem is the initial step to examine the way in which different repertoires of action and organization employed, different tactics, can be related to different modes of production of subjectivities.

\section{Searching for Words}

The search for bibliographies that helped to understand what militancy would be brought attention to the sociology of militant engagement. The review work by Sawicki and Simeant (2011) points out that the current challenges of understanding this field are linked: (a) to the methodological improvement and diversification of studies that explain the ways in which individuals engage in militant careers; (b) to the continuity and expansion of the investigations about the different retributions for the subjects coming from the militant engagement; (c) the proposal of a close examination of the relationship between macrossocial transformations and the composition and organization of militancy. In characterizing militant engagement as "any form of collective participation aimed at defending or promoting a cause" (Sawicki \& Simeant, 2011, p. 120), the authors use militancy as a kind of "adjective", which qualifies a specific form of engagement of subjects into causes. In addition, this use also indicates the relation of the term with the participation in movements in defense of causes and formation of associations and groups of people in defense of collective interests.

The dossier "Education and politics: new configurations in practices of militancy", published by the academic journal Pro-Posições (vol. 20, n. 2, 2009) addresses the subject in a multidisciplinary way, highlighting the anthropological, sociological and political aspects of the topic. In the introductory section, the work is characterized as "fundamental reference for researchers engaged in the topic of militant engagement, as well as contribution to an increasingly necessary debate on the theoretical and methodological frameworks of studies on political phenomena" (Engelmann, 2009, p. 19). The collection of articles on the subject published by Cadernos CERU (vol. 20, n. 1, 2009), presented by Lucena, Tomizaki and Campos (2009), already has its relevance justified by the diversification, expansion and complexity of the spaces of political participation and also by the urgency of forging theoretical and analytical tools more suitable for circumscribing militant experiences.

Using the keyword "militancy", we conducted a literature review in the SciELO database in March 2016 and found 102 articles. A reading of the abstracts, seeking to synthesize a definition that would allow us to understand the 
uses of the term, indicated the use of the word sometimes as an adjective, naming the way individuals engage and "fight" for specific causes, and other times, as a noun identifying a group of people acting together, that would define a subject, or a group, engaged in a cause to defend it. The term appears more frequently in the literature that discusses social movements, political parties and collective action and the use of the same is carried out similarly to that which was done by the president of the Workers' Party.

In Ruy Falcão's speech, the party directories, the trade unions and other dispositifs are qualified as militants, and, at the same time, the speech claim these devices to assemble their militancies. Such uses suggest a naturalization of the idea, treating it as self-evident, which would require no greater definitions or conceptualizations.

When one evokes the image of a militant, the individual who easily comes to mind is someone who speaks firmly and is willing to sacrifice for a cause ... We see that a militant / martyr who is even willing to die in the name of his ideals is often put on the scene. (Oliveira et al., 2009, p. 1807)

As Canguilhem (2014) observed: "As soon as we seek what would make life a means, seeking a reason to live, we also find reasons to lose life" (p. 88). From this it is possible to deduce the common assumption that militancy would produce a specific mode of investment from the individuals in the activities, marked by force and vigor, and also by the position of availability and sacrifice of their personal needs in the name of the defense of an ideology. Part of the results achieved by Baltazar (2004) in an exploratory study on the perception of the effects of militant engagement on the personal aspects of daily life of militants reinforces this assumption.

The following are indicated as consequences of militancy: the lack of time for personal activities, damages to professional life, interference in

Dès que l'oncherchecedont la vie devraitêtre le moyenencherchantune raison de vivre, on trouveaussi des raisons de perdre la vie. the continuity of the formal education and the challenge to reconcile the militant activities with the demands of the family nucleus. It is interesting to note the author's remarks in presenting these results: "That is not to say that with this militancy we are trying to reinforce a very recurrent idea among many militants and even former militants that involvement and participation in various forms of popular organization generate suffering and pain" (Baltazar, 2004, p. 188).

Melo (2010), addressing cinematic discourses about the military dictatorship in Brazil, emphasizes that the representation of the militant is made by the exaltation of his capacity to resist. "The real and constructed scenes bring soldiers with tanks and militants on foot, in a confrontation that symbolizes the struggle of the weakest, holding hands and mouths sealed with stickers to indicate the silencing caused by repression" (Melo, 2010, p. 77). Alves (2012), in a similar work, emphasizes, among the meanings attributed to militancy in the works studied, the militants' ability to resist and the effects of the positions defended by them on their friends and families. Underlining the way in which the discursive representations of militancy in culture are presented, punctuating the span creating the imaginary side of the subject at hand, herein fulfills the function of helping to support the hypothesis that a militant position would increase the vigor and capacity to sustain the resistance of an individual. In order to investigate the ways of using the term collected so far, we propose to define militancy as a methodology to produce collective action aiming to intervene, or to interfere, in current social norms. In Brazil, this methodology has become one of the prime strategies to trigger, to manage and to monitor many forms of collective action. From the field of studies on warfare techniques, strategy refers to "how to organize, plan, and guide the various combats (campaigns and operations), taking into account a joint vision of all the forces upon which it depends, as well as the enemy forces, in order to achieve a fixed goal: to win the war against certain adversaries" (Harnecker, 2012, p. 63). 


\section{Militancy: Some Whats, Whichs and a Few Buts}

Valverde (1986) opens his studies on militancy stating that

The military is the organization of the movement according to the logic of war: military is the opposition of space and time in an operational relationship, the determination of a place and a moment of a certain warlike action. Military, therefore, is still, the very action that takes place on the topology and the chronometry of the battlefields. (p. 60)

Militancy and Power (Valverde, 1986), whose initial objective was to carry out a historiographic analysis of the conditions of decline of anarcho-syndicalist tendencies and the rise of communist leaderships on the Brazilian proletariat, ends up deviating to a genealogy of militancy, whose merit lies in locating, indicating and analyzing "the mechanisms by which the militant body is constituted, subject to the devices of power and knowledge engendered by militancy" (p. 182). In the texts of the meetings of Communist International, in the works of Marx and Lenin, and in the publications by the Brazilian trade union movements, the research points out how the production of militant engagement was built on a regime of exercising disciplinary power, centralized and totalitarian, which holds subjectivation as its main dispositif ${ }^{2}$ in the party; In militant engagement, one of the tactics for the production of docile bodies; And in obedient, reactive, committed and resentful subjectivity, the guarantee of continuity of the militants' engagement within the guidelines defended by the movement.

In a text about the role of the members of the Communist Party in the conduct of the

\footnotetext{
The word dispositif is being used to name "a) a heterogeneous, linguistic and non-linguistic set, which includes virtually anything in the same title: speeches, institutions, buildings, laws, police measures, philosophical propositions, etc. The device is in itself the network that establishes itself among these elements" (Agamben, 2014, p. 25). Thus, it will always execute a strategic function in a set of relations of knowledge and power.
}

revolution, Ernesto Che Guevara (2010) makes these ideas explicit by stating that the militant would be

an advisor who puts into concrete directives the sometimes obscure desires of the masses; A relentless worker who gives everything to his people, a suffering worker who gives his hours of rest, his personal tranquility, his family or his life to the revolution. (Guevara, 2010, p. 129)

Soldiers of the party, the mission of whom is to make people aware of the need for Revolution. Combatants dedicated full-time to the revolutionary cause. These militant martyrs would carry the set of attributes necessary for the fulfillment of the arduous task that they propose to confront the present and bring the future.

Mapping the different figures of subjectivity, Rolnik (2014) does not hide the astonishment when encountering the militant:

The first thing that catches the cartographer's attention is the epic-dramatic vision that revolutionaries have of history: they say they obey the program of the line of destiny to which all peoples will one day necessarily be subjected. This line, they explain, is totally predictable: you just have to "become aware" and "assume it". The cartographer notes that the line they envisage is that of their party, a line which, according to them, would inevitably lead them, in a revisionist or radical way (i.e. with or without degrees), to the promised land of revolutionary society. That's why they defend it tooth and nail. That is why, he understands, this is the discourse and attitude of some people that surround fanaticism. (Rolnik, 2014, p. 128) The cartographer lists two founding myths of militant subjectivation: the popular national cultural identity and the revolution. From the first emergence: (a) the affirmation of identity and crystallized existential territory, ideally located in a glorious past where the enemy did not yet exist; (b) the understanding of the dimension of individual desires and needs exclusively as capturing the bourgeois model of life; (c) the tendency to organize their discourses and activities by the contempt and deconstruction of the 
present time - macropolitically dominated by the enemy. From the second, emanating part of the force that makes them endure the hard concrete reality in which they fight their battles, since it is the unrestricted defense of this revolutionary future that would make the present habitable. "What feeds them in their militant culture, from this point of view, is to imagine themselves bloody chested in the trenches flagged by the revolutionary struggle, succeeding in putting an end to this reality they consider to be cursed" (Rolnik, 2014, p. 133).

Macedo and Silva (2009) point to the communist militant as being the model of the political militant of the 20th century. "Faith, hierarchy and discipline constitute the explanatory triad of this total militant, engaged in an organized and devout way in the transformation of society" (Macedo \& Silva, 2009, p. 379). Impossible to get in touch with this support tripod and not perceive in it resonances of Freud's discussions in Group Psychology and Ego Analysis (1921/2006). In this work, the author pointed out that the support of the grouping of institutions such as the army and church are based on the illusion that, when entering these groups, the individual becomes loved by a superior leader, integrating himself with a mass of individuals he loves unconditionally and by whom he is loved. It is in this way that Freud explains the cohesion and lack of individual freedom of a subject integrated into groups. Mezan (2006), pondering the effects of a group founded on such characteristics, reinforces the hypothesis that militancy would impart strength and vigor to the militants. The author is precise in stating that "while the mass lasts, aggressiveness is inhibited within it, being diverted to those who do not belong to it (military enemies or believers in other religions)" (Mezan, 2006, p. 154).

Veiga-Neto (2012) provides other illustrative elements on the effects of using the tripod (faith, hierarchy and discipline) as a form of organization. "It is not for the militants to continually question the ideology that guides their actions; they must follow, along with their peers, the actions and precepts already drawn by a few" (p. 273). As a result of this organizational model, the militant is produced: (a) subjectivated from a hierarchical disciplinary perspective; (b) aware of the need for personal martyrdom as a condition for asceticism in an ideal post-revolutionary world; (c) libidinally linked to their peers by a need for recognition; (d) oriented to position themselves within a war topology. Fighting on behalf of a cause, "the militant is, in fact, a soldier in the service of his law; and he will be a much a better soldier insofar as his obedience comes from his inner option, from his conscience and not from regulatory mechanisms" (Valverde, 1986, p. 92).

Considering Silva's (2004) caveat about the risks arising from the naturalization of some ideas, observing how the term was used in the studied literature and taking into account all the considerations made so far, the following questions become relevant: Does the militant methodology endure in us as a way of producing collective action to make changes? If we admit that "modernity was built around the ideology of the revolution, which materialized, as a metaphor, the transforming belief of the collective subject [but] the postmodern actuality threw a shovel of lime at such a pretension" (Birman, 2007, p. 82 ), do we still identify in militancy a way of producing collective action to challenge existing norms? Is it possible to produce "movements of change and rupture" outside "the themes, concepts, methods and institutions derived from Marxist science" (Valverde, 1986, p. 182)?

All these inquiries were made intending to provoke and, to a certain extent, reinforce the need to denaturalize the current use of a term that frequently appears in the discourses of those who work to intervene in current social norms. The tautological use of the expression militancy in the bibliography consulted - that in which militancy is confused with the act of military - would already justify the need to launch the militant methodology to the status of a problem. The imperative of tactical repositioning and readjustments in the face of current socio-historical conditions, uphold the necessity of a research. What model of society will we have to create now that communism, social democracy, and national populism are discredited as alternatives 
to the problems experienced in representative democracies of the Western world (Mouterde, 2003)? Does faith, hierarchy, and discipline remain as the proper tripod to produce engagement? How productive have the tactics of militancy and militants been to guide forms of social and collective action in the direction of "changing the existing social order, or part of it, and influencing ... institutional decisions of governments and agencies regarding the definition of public policies" (Machado, 2007, p. 253)?

The materials studied indicate the field of militant engagement as marked by disputes of polarized models and positions, structural tensions, irreconcilable antagonisms and insoluble paradoxes, which usually demand that subjects that enter take a position (Silva, 2003). In this regard, we note that the considerations made do not aim to deprive of merit the innumerable initiatives developed by militants of various causes. The critical and decisive tone adopted is maintained to expose - wherever there is innovation, progress and transformation - the update of mechanisms for disciplining bodies and controlling populations that engage in collective action aiming to produce changes in the current social order. The attentive look aims to interrogate the present in order to map the ways of producing differences that already express themselves therein. After all, the question of Foucault (1977) expressed in the American introduction to Anti-Oedipus: "How can we not become a fascist even when (especially when) believing being a revolutionary militant?" (p. 3).

\section{The Attentive Look Upon Repetition Makes the Difference}

Baltazar (2004), in the research entitled "The encounters and disagreements of militancy and everyday life" points to the existence of contradictions between the discursive positions of the militants and some practices in their private life. In a very suitable footnote to the considerations presented here, the author informs that, in the course of her work, she had access, in informal research spaces, to complaints about "militant husbands", "militant boyfriends" and "militant fathers" whose posture in domestic life is incompatible with their militant discourses. Bringing this extra information to the plane of the conclusive questions of the research, the author points out the challenge of

expressing in this practice [militancy] not only the rational aspect of the need to overcome the most diverse forms of exploitation and injustice, but also to express the affective and emotional, feeling the need for change and internalizing this practice. (Baltazar, 2004, p. 189)

Vasconcelos and Paulon (2014), analyzing some sensitive points in the form of militant action in favor of the Brazilian psychiatric reform, ponder the effects of the exercise of an eminently identitarian militancy mode that operates in a reactive and resentful logic in Nietzschean's terms (Kehl, 2004). After all, "the parameter is always another with which one fights against, instead of struggling to affirm life" (Vasconcelos \& Paulon, 2014, p. 231). In line with this logic, the action repertoire of militant privileges, as a tactic, the disqualification of opposing positions and the radical opposition between movements that militate for different causes making it the construction of interfaces and the visualization of the common dimension of claims that are being made difficult.

Mesquita (2003), in a study dedicated to investigating the militant practices of the Brazilian university student movement from the influence of the new social movements (NSM), points to the existence of harsh criticisms of the centralized, hierarchical and bureaucratic form of student militancy action. Still, the presence of a strong questioning of political-partisan action about this militancy stands out. By equipping entities such as the National Union of Students, the various parties end up reducing the assemblies and forums of the students to spaces for continuity of the articulation of the party guidelines. The rigging would also produce a style of intervention centered on persuasion and awareness, leaving little or no room for the shared construction of work schedules and understanding of the needs of the students themselves. Finally, the research gave visibility to the 
emergence of a new militant sociability in the student movement, opposing the more traditional practices of student militancy, a reproducer of institutionalized political behavior that is (re)produced in the support spaces for the student movement such as the parties, unions, etc. (Mesquita, 2003, p. 135)

Based on more horizontalized relationships, valuing the more subjective dimension of engagement, with decentralized and relatively autonomous forms of organization, investing in experiential pedagogical strategies not restricted to argumentative practices of rational conviction, this "new militant sociability" has been strengthened in the traditional modes and thus has been gaining space within the student movement. The incorporation of such characteristics of the "new logic of militancy" has been an alternative to the emptying of the spaces for student participation, since it produces, recognizes and puts into operation other devices of participation beyond the directories, committees and academic centers.

The Course Executives (who despite some time of existence only strengthened and gained greater visibility in the last decade), cultural groups, groups of black students, university extension groups held by students, university women's groups, etc. are the signs of these new languages. (Mesquita, 2003, p. 135)

Saraiva (2010) characterizes the new social movements (NSM) as a diverse set of movements, endowed with an equally diverse nature, whose focus would not necessarily be based on the notion of social class and social structure, but rather on the consideration of issues such as culture, identities, gender, race and ethnicity, among others. The author clarifies that "although it does not aim at the conquest of power, the movements generate demands to be met by the State, thus facilitating the installation of a process of democratization of society" (Saraiva, 2010, p. 9). Machado (2007) points out the perspective by which the movements enter into relationships with the State as a novelty - the relation that was once constituted by the path of the opposition, and has come to be articulated in terms of cooperation. According to him,

the initiatives of civil society embodied in the action of social movements . . . instead of being seen as subversive, revolutionary or marginal, come to be understood as their own, typical and even healthy manifestations of a plural political and social environment. (Machado, 2007, p. 255)

There is little consensus on what would actually be new in the field of social movements. We will start from the opinion of Gohn (2006), when he says that the novelty is the politicization of new themes and a new way of doing politics. Is this new form of politics producing a change in the common methodologies used to intervene in social norms? Are they producing a "new logic of militancy, a new militant sociability" (Mesquita, 2003, p. 136)? In the face of such changes, is the term militancy still appropriate? In this aspect, it may be useful to call up for the discussion the precise words with which Foucault (2015) positions himself in relation to a controversy generated from some of his statements on the question of homosexuality:

"A combat cannot always perpetuate itself on the same terms, otherwise it is sterilized, immobilized, succumbed to traps. Soon, a change of battle front. And, consequently, a change of vocabulary. The change of objectives is also absolutely indispensable" (pp. 6-7).

Veiga-Neto (2012) presents "activism" as an alternative term to militancy. "Activism, activating, attitude, action, agitating, acting and taking action are part of the same semantic field that refers to the Latin form agěre: ag (onward, forward) + gerěre $=$ to push forward, make advance"(p. 273). Is activism a more precise term for the modes of engagement, the repertoires of action, and the tactics carried out by the actors within the NewSocial Movements? Is activism a more appropriate term in the current scenario to deal with the changes in collective actions repertoires, and in the tactics used by part of the actors in New Social Movements in Brazil? 


\section{Activate and Occupy}

Although in the Brazilian context activist/ militant expressions are used as synonyms, it is fundamental to emphasize that they have different connotations, as can be seen in Saraiva's (2010) considerations on their use in his study on the "Movimento Passe Livre" (MPL).

At the beginning of the movement, there was an intense debate about the term to be used to define the action of its members within the scope of the MPL: on the one hand, many defended the use of the term militancy, since it is already used to designate the action of a person in a political and social movement, bringing to mind a notion of responsibility and commitment; on the other hand, other members advocated the use of the term activism, precisely because it is not so widely used in Brazil and, therefore, differentiates itself from the meanings usually attributed to the term "militancy" that denoted postures and attitudes from which one wanted to be removed. (Saraiva, 2010, p. 3)

The extract explains the intention of the members of MPL, considered by authors of the area as a legitimate representative of the New Social Movements (Scherer-Warren, 2014a, $2014 b$ ), to demarcate a distancing of the meanings attributed to militancy. Seidl (2014) points out that there is an attempt by the new movements to deny the model of union and party organization, of which the notion of militancy is correlative, by criticizing in it an excess of centralization of information and decisions, asymmetry in relationships of power and little space for participation by the members in the construction of the actions to be developed. Veiga-Neto (2012) lists distinctions that aid understanding.

Militancy - as an action militaris - and activism are both of the order of acting forward, of action for a change of position, of action to a different situation than one

Free Pass Movement has. But while it is governed by the logic of hierarchical obedience, it is based on the greatest freedom possible and permitted by the combination of the thinkable-sayable and the visible dyad. (p. 273)

Saraiva (2014) clarifies that there is, within the MPL's practical and discursive organization, an attempt to distance itself from what it calls the "institutional left", represented by non-governmental organizations, student organizations (National Student Union, Central Academic Directories, etc.), political parties, trade unions and other social actors. In the sense of the MPL activists, these organizations have markedly self-referenced activity, using people and situations as a manipulated mass to achieve their own ends. In addition, these are hierarchical organizations with an orthodox and teleological reading of social classes, with a predominant focus on a single revolutionary subject: the working class; they do not usually understand or deal with the multiplicity of subjects and struggles within the class itself. (Saraiva, 2014, p. 43) Jefrey Juris (2006), pointing out characteristics listed as important by the young activists who participated in the World Social Forum in Porto Alegre, in 2006, emphasizes the valorization of the logic of network organization to the detriment of what he calls a logic of command.

This latter [logic of command] would be present in all traditional formations, such as political parties and trade unions, based on the recruitment of new members, the construction of unified strategies and the struggle for hegemony. In contrast, the first [network organization] would involve the creation of a wide umbrella of spaces, to which the various movements would converge around a small common core of positions/principles, preserving their autonomy and specificity. Rather than recruiting new members to any particular organization, the goal becomes horizontal expansion, by connecting with existing movements, organizations and networks. (Juris, 2006, p. 6) 
The Movimento Passe Livre São Paulo (MPL, 2013), in describing its intentions and its mode of organization, presents itself as an agglutinator of social participation and citizen engagement, self-managed, with a strong appeal to horizontality in the exercise of power relations, and with cross-sectional agenda for the social classes - human mobility in urban centers.

The Arab Spring, the Outraged at the Plaza Del Sol in Madrid and the Occupy movements in the United States are also expressions of this "new" mode of social movement and citizen participation. An analysis of the tactics of organization and functioning of these protests (Castells, 2013) highlighted: networking with several other movements; occupation of urban spaces as a way of giving visibility to the cause under debate; preservation of participants' autonomy; strategic use of new information and communication technologies; preference for direct participatory methodologies for collective decisionmaking; construction of progressive consensuses and absence of formal leadership. It is essential to point out that such movements radically question the ability of political parties and other traditional political institutions to represent the interests of the majority of the population. In doing so, they take up and update assumptions of action and organization present in other movements, such as: anarchism by Mikhail Bakunin and Joseph Proudhon; the Zapatista movement of Mexico; Movimento dos Trabalhadores Sem Terra $^{4}$ (MST) of Brazil; German Autonomous Worker's movement of 1980; among others (Day, 2005).

Slavoj Zizek (2013), in his accurate reading on the claims of the Occupy Wall Street movement, points to two central issues:

Discontent with capitalism as a system (the problem is the capitalist system itself, not its corruption in particular); the awareness that the form of multiparty democracy is not enough to combat capitalist excesses (i.e., that democracy must be reinvented) (Zizek, 2013, p. 104).

\footnotetext{
4 Movement of Landless Workers.
}

In the national literature, the expressions activism and militancy are predominantly used as synonyms. Defined as methodologies to produce collective action aiming to intervene in current social norms, they could not be used in such a way, since, with this, the differences are homogenized and extinguished to existing powers of change. Would there be something in the activities of the New Social Movements, which can serve as an indication of renewal in the face of the crisis of representativity that we are experiencing at the dawn of the 21 st century? Are there in this revival of autonomist ideals indications of a renewal in the methodologies to produce collective action aiming to challenge the prevailing order? Is it possible to see, in the streets and in the forms of action of these actors, clues that make the reconstruction of politics possible? We believe that,

in a moment of crisis, of the generalized questioning of the great theoretical paradigms, the confrontation with the empirical reality and the open attention to the new, to what is being born, to what some call immediate history, are more than ever, necessary. (Mouterde, 2003, p. 170)

Political experiences strongly embedded in the issues brought to the forefront by these new social movements have shared with us the aforementioned focus. Conscious of the limits of our model of a multiparty representative democracy, but taken by the urgency of proposing alternatives to the debate within the current democratic institutional framework, organizations such as Syryza in Greece, the movements of citizen candidacies and the formation of the Podemos in Spain are significant expressions of these attempts at democracy (Cava \& Béltran, 2014).

\section{Final Considerations}

At the beginning of 2016, the crisis of the western representative democracies was summed up, in Brazil, to a crisis of governability and institutionality that circulated in various public media phrases of discouragement such as "a government that is not worth defending, an 
opposition is not worth supporting, a justice that cannot be trusted, a press that is not worth believing, a population that is not worth talking to". To change the terms in which the debate is set, to present differences where one sees identity, to make a diagnosis of the present, and to identify the available virtualities available to reinvent the future. "This is, in my view, the role that intellectuals can and should play, and among them, researchers in the social sciences, citizens like others, but who have more time than others to study" (Piketty, 2014, p.11).

Presenting a distinction between activism and militancy does not aim to create a sterile taxonomy with the pretense of objectifying reality. This is a proposal to denature common terms in the debate over collective action. Explaining the silence in the national literature about the differences between activism and militancy, it is giving visibility to the differences in the ways of operating, feeling and acting that can be grouped within these terms. Moreover, starting from Deleuze's premise that a problem will have its answer conditioned by the precision of the terms in which it was proposed (Deleuze, 1988), we understand that bringing militancy back to the status of a problem can create a zone of visibility of both the inadequacies of the militant methodology today as well as a glimpse of pathways which looks powerful for reinventing ourselves and rebuilding the modes of intervening in social norms.

Our study of the subject in question is still ongoing, since it is the object of a doctoral thesis of one of the authors. However, recognizing the political dimension of the act of producing knowledge, it was necessary to make what we are producing public. Aware of the need to find theoretical tools to formulate the problem, we hope, with this text, to start the debate that leads us to be less fascist, especially when we believe we are revolutionaries.

\section{References}

Agamben, G. (2014). O amigo \& o que é um dispositivo? Chapecó, RS: Argos.
Alves, R. V. (2012). Em exibição nos cinemas: A representação discursiva da militância de esquerda e da resistência na ditadura militar (Master's thesis, Universidade Estadual de Maringá, Maringá, SC, Brazil). Retrieved from http://www. ple.uem.br/defesas/pdf/rvalves.pdf.

Baltazar, B. (2004). Os encontros e desencontros da militância e da vida cotidiana. Psicologia: Teoria e Pesquisa, 20(2), 183-190. doi: 10.1590/ S0102-37722004000200011

Birman, J. (2007). Mal-estar na atualidade: A psicanálise e as novas formas de subjetivação $\left(6^{\text {th }}\right.$ ed.). Rio de Janeiro, RJ: Civilização Brasileira.

Canguilhem, G. (2014). Ouvres Complètes, tome iv. Résistance, philosophie biologique et histoire des sciences 1940-1965. Paris: J. Vrin.

Castells, M. (2013). Redes de Indignação e Esperança. Rio de Janeiro, RJ: Zahar.

Cava, B., \& Béltran, S. A. (Eds.). (2014). Podemos e Syriza: Experimentações políticas e democracia no século 21. São Paulo, SP: Annablume.

Day, R. J. F. (2005). Gramsci is dead: Anarchist currents in the newest social movements. London: Pluto Press.

Deleuze, G. (1988). Diferença e repetição (L. Orlandi \& R. Machado, Trans.). Rio de Janeiro, RJ: Graal.

Engelmann, F. (2009). Apresentação. Pro-Posições, 20(2), 17-19. doi: http://doi.org/10.1590/S010373072009000200002

Foucault, M. (1977). Introdução à vida não fascista. In G. Deleuze \& F. Guattari, Anti-Édipo: Capitalismo e esquizofrenia (pp. 3-4). Lisboa: Assírio e Alvim.

Foucault, M. (2015). O saber gay. Ecopolitica, 11, $2-27$.

Freud, S. (2006). Psicologia de Grupo e Análise do Ego. In S. Freud, Edição Standard Brasileira das Obras Psicológicas Completas de Sigmund Freud (Vol. XVIII, pp. 79-154). Rio de Janeiro, RJ: Imago. (Original work published 1921)

Gohn, M. G M. (2006). Teoria dos movimentos sociais: Paradigmas clássicos e contemporâneos ( $5^{\text {th }}$ ed.). São Paulo, SP: Edições Loyola.

Guevara, E. C. (2010). O Partido Marxista-Leninista. In A. Bogo (Ed.), Teoria da organização política-escritos de Mariátegui, Gramsci, Prestes, 
Che, Ho Chi-minh, Marighella, Álvaro Cunhal, Agostinho Neto, Florestan Fernandes (Vol. II, pp. 119-130). São Paulo, SP: Expressão Popular.

Harnecker, M. (2012). Estratégia e Tática (2 $2^{\text {nd }}$ ed.). São Paulo, SP: Expressão Popular.

Juris, J. (2006). Youth and the world social forum. Retrieved from http://ya.ssrc.org/transnational/ Juris/

Kehl, M. R. (2004). Ressentimento. São Paulo, SP: Casa do Psicólogo.

Lucena, C. de T., Tomizaki, K., \& Campos, M. C. S. de S. (2009). Apresentação. Cadernos CERU, 20(1), 7-13.

Macedo, E. A., \& Silva, A. J. (2009). Militante trotskista: O dissidente por definição. Anais do IV Congresso Internacional de História, 377387. doi: 10.4025/4cih.pphuem.398

Machado, J. A. S. (2007). Ativismo em rede e conexões identitárias: Novas perspectivas para os movimentos sociais. Sociologias, 18, 248-285. doi: $10.1590 / \mathrm{S} 1517-45222007000200012$

Melo, P. B. (2010). A intervenção cultural do discurso cinematográfico: Os sentidos da ditadura militar no Brasil. Revista FAMECOS, 17(2), 68-80.

Mesquita, M. R. (2003). Movimento estudantil brasileiro: Práticas militantes na ótica dos novos movimentos sociais. Revista Crítica de Ciências Sociais, 66, 117-149.

Mezan, R. (2006). Freud, pensador da cultura. Rio de Janeiro, RJ: Companhia das Letras.

Mouterde, P. (2003). Reinventando a utopia: Práticas alternativas da esquerda latino-americana. Porto Alegre, RS: Tomo Editorial.

Movimento Passe Livre. (2013). Não começou em Salvador, não vai terminar em São Paulo. In C. Vainer, D. Harvey, E. Maricato, F. Brito, J. A. Peschanski, J. L. S. Maior, ...V. A. Lima, Cidades Rebeldes. Passe Livre e as manifestações que tomaram as ruas do Brasil (pp. 12-18). São Paulo, SP: Boitempo.

Oliveira, G. N., Pena, R. S., Amorim, S. C., Carvalho, S. R., Azevedo, B. M. S., Martins, A. L. B., \& Guerra, M. B. (2009). Novos possíveis para a militância no campo da Saúde: A afirmação de desvios nos encontros entre trabalhadores, gestores e usuários do SUS. Interface (Botucatu), 1(13), 523-529.
Piketty, T. (2014). O capital no século XXI. Rio de Janeiro, RJ: Editora Intrínseca.

Rolnik, S. (2014). Cartografia sentimental -Transformações contemporâneas do desejo ( $2^{\text {nd }} \mathrm{ed}$.). Porto Alegre, RS: Editora Sulina.

Saraiva, A. C. (2010). Movimentos em movimento: Uma visão comparativa de dois movimentos sociais juvenis no Brasil e Estados Unidos (Doctoral dissertation, Universidade de Brasília, DF, Brazil). Retrieved from http://repositorio.unb. br/bitstream/10482/6974/1/2010_AdrianaCoelhoSaraiva.pdf

Saraiva, A. C. (2014). Movimento Passe Livre e Black Blocs: Quem são os novos atores que emergiram dos protestos de 2013. In A. D. Cattani (Ed.), Protestos: Análises das ciências sociais (pp. 4152). Porto Alegre, RS: Tomo Editorial.

Sawicki, F., \& Simeant, J. (2011). Inventário da sociologia do engajamento militante: Nota crítica sobre algumas tendências recentes dos trabalhos franceses. Sociologias, 13(28), 200-255.

Scherer-Warren, I. (2014a). Dos movimentos sociais às manifestações de rua: $\mathrm{O}$ ativismo brasileiro no século XXI. Política \& Sociedade, 13(28), 13-34.

Scherer-Warren, I. (2014b). Manifestações de rua no Brasil 2013: Encontros e desencontros na política. Caderno CRH, 27(71), 417-429.

Seidl, E. (2014). Notas sobre ativismo juvenil, capital militante e intervenção política. Política e Sociedade - Revista de Sociologia Politica, 13(28), 63-78.

Silva, A. J. (2003). A formação do militante anarquista: Primeiros movimentos para uma leitura distinta (Doctoral dissertation, Universidade Federal do Paraná, Curitiba, PR, Brazil). Retrieved from http://acervodigital.ufpr.br/bitstream/ handle/1884/24591/T\%20-\%20SILVA, \%20 ANGELO\%20JOSE\%20DA.pdf?sequence=1

Silva, R. N. (2004). Notas para uma genealogia da Psicologia Social. Psicologia \& Sociedade, 16(2), 12-19.

Valverde, M. E. G. L. (1986). Militância e poder: Balizas para uma genealogia da militância (Master's thesis, Universidade Estadual de Campinas, SP, Brazil). Retrieved from http://www.bibliotecadigital.unicamp.br/ document/?view=000017675 
Vasconcelos, M. F. F., \& Paulon, S. M. (2014). Instituição militância em análise: A (sobre)implicação de trabalhadores na Reforma Psiquiátrica brasileira [Special issue]. Psicologia \& Sociedade, 26, 222-234. doi: 10.1590/S010271822014000500023

Veiga-Neto, A. (2012). É preciso ir aos porões. Revista Brasileira de Educação, 17(50), $267-$ 282.

Zizek, S. (2013). Problemas no Paraíso. In C. Vainer, D. Harvey, E. Maricato, F. Brito, J. A. Peschanski,
J. L. S. Maior, ...V. A. Lima, Cidades Rebeldes. Passe Livre e as manifestações que tomaram as ruas do Brasil (pp. 101-108). São Paulo, SP: Boitempo.

Received: $25 / 07 / 2016$

$1^{\text {st }}$ revision: $21 / 02 / 2017$

Accepted: 09/04/2017 